\title{
Analisis Faktor-Faktor yang Berhubungan dengan Partisipasi Pembudidaya Ikan Bandeng (Chanos Chanos) dalam Kegiatan Kimbis di Kecamatan Blanakan Kabupaten Subang Provinsi Jawa Barat
}

\author{
[Analysis of Factors Relationship Milkfish Grower's Participation on KIMBis Program \\ in Blanakan, Subang Regency, West Java Province] \\ Aripudin, Andin H. Taryoto, Maimun \\ Jurusan Penyuluhan Perikanan - Sekolah Tinggi Perikanan \\ Jalan Cikaret Nomor 2 Bogor, Jawa Barat \\ Diterima: 30 Mei 2016; disetujui: 29 Juli 2016
}

\begin{abstract}
Abstrak
Untuk dapat meningkatkan kemauan dan kemampuan masyarakat pesisir dalam menerapkan aplikasi teknologi, maka dilakukan kegiatan Klinik IPTEK Mina Bisnis (KIMBis). Penelitian ini bertujuan untuk menganalisis a) perkembangan KIMBis Subang; b) karakteristik individu, luas jejaring komunikasi kelompok, motivasi dan partisipasi pembudidaya ikan bandeng; c) hubungan karakteristik individu, luas jejaring komunikasi kelompok dan motivasi pembudidaya ikan bandeng dengan partisipasi dalam kegiatan KIMBis. Penelitian ini dilaksanakan pada bulan Januari-Maret 2016 di Kecamatan Blanakan Kabupaten Subang Jawa Barat. Populasi dalam penelitian ini sebanyak 20 kelompok pembudidaya ikan bandeng. Metode yang digunakan untuk menentukan jumlah sampel menggunakan rumus Slovin dengan batas toleransi kesalahan 10\%. Data dianalisis dengan menggunakan korelasi pearson product moment dengan nilai $\alpha=0,05$. Hasil penelitian menunjukkan bahwa perkembangan program KIMBis Subang dilihat dari luas wilayah binaan telah mencapai 17 Desa di 4 Kecamatan, telah mendapat dukungan pemerintah daerah Kabupaten Subang dan instansi terkait serta respon positif masyarakat yang telah mengikuti kegiatan KIMBis. Sistem budidaya ikan secara polyculture mampu meningkatkan pendapatan pembudidaya serta sedang dirintis pengembangan kawasan budidaya ikan secara polyculture menjadi kawasan Ekowisata Wanamina. Hasil analisis dengan menggunakan korelasi pearson product moment menunjukkan pengalaman, luas jejaring komunikasi dan kebutuhan untuk kesejahteraan berhubungan signifikan dengan partisipasi dalam kegiatan KIMBis.
\end{abstract}

Kata kunci: Blanakan, Karakteristik, KIMBis, Partisipasi, Pembudidaya.

\begin{abstract}
To promote the ability of coastal community in implementing technology, KIMBis (consultation services on technology to support fisheries businesses) was implemented by Ministry of Marine Affairs and Fisheries. This research objectives are: a) to analyze the development of KIMBis program in Blanakan region; b) to analyze the characteristics, motivation, network of group communication and participation in KIMBis activities of milkfish growers' in Blanakan region; and c) to identify the relationship of Blanakan milkfish growers' characteristics, motivation and communication networks to their participation to KIMBis program. This research was conducted on January-April of 2016 in Blanakan, Subang Regency, West Java Province. The population is 20 groups of milkfish growers' in the Blanakan Subang, and 73 samples of milkfish growers'. Sampling was based on a Slovin formula with $10 \%$ error tolerance. Pearson product moment correlation method at $\alpha=0,05$ level was used to analyze the data. Research results indicated that the development of KIMBis program in Blanakan has covered 17 villages in four districts, significant government support of Subang Regency and related
\end{abstract}

$\triangle$ Penulis korespondensi

Alamat surel : andintea@yahoo.com 
agencies were identified, and positive responses of milkfish growers' to participate in KIMBis activities. Milkfish polyculture system wer applied to increase milkfish growers' income. The development of milkfish polyculture system into Forestry-Fish ecotourism (Ekowisata Wana Mina) was being initiated. Pearson correlation method indicated that milkfish growers' experiences, network of communication and welfare orientation were correlated significantly to their participation KIMBis program.

Keywords: Blanakan, Characteristics, Growers', KIMBis, Participation,

\section{PENDAHULUAN}

Salah satu pendekatan yang akan mampu digunakan untuk meningkatkan kapasitas individu, yaitu dengan melalui penyediaan kemudahan akses terhadap teknologi. Hal ini juga perlu dilakukan karena berdasarkan fakta-fakta bahwa rendahnya adopsi tentang teknologi oleh masyarakat pesisir dapat disebabkan oleh permasalahan yang terus menerus seperti kesulitan modal usaha serta lemahnya manajemen usaha sehingga masyarakat tidak dapat meningkatkan kesejahteraannya. Rendahnya tingkat adopsi teknologi tersebut menyebabkan produk yang dihasilkan tidak sesuai dengan keinginan pasaran, sehingga diperlukan upaya perbaikan melalui aplikasi teknologi dalam suatu kegiatan produksi oleh/dari masyarakat. Untuk meningkatkan adopsi teknologi, salah satunya adalah melalui peningkatan partisipasi pembudidaya ikan bandeng dalam kegiatan KIMBis.

Permasalahan yang dihadapi oleh pembudidaya ikan bandeng di kawasan Kecamatan Blanakan Subang adalah produktivitas dari kegiatan usaha budidaya ikan bandeng rendah (200 $\mathrm{kg} / \mathrm{ha}$ ) dan adopsi teknologi yang rendah. Setelah adanya program KIMBis, kegiatan budidaya ikan bandeng yang semula hanya dilakukan secara monoculture sekarang sudah beralih menjadi budidaya polyculture dimana setiap hektar lahan tambak bisa menghasilkan 1,6 kwintal ikan bandeng, 50-70 kg Udang Windu, dan 15-20 ton Rumput Laut basah atau setara dua ton rumput laut kering (Junaidi, 2015). Berdasarkan tahapan uraian yang telah dikemukakan diatas, dapat diuraikan perumusan masalahnya yaitu :

1. Bagaimana perkembangan program KIMBis di Kecamatan Blanakan?

2. Bagaimana karakteristik, jejaring komunikasi kelompok, motivasi dan partisipasi para pembudidaya ikan bandeng dalam kegiatan KIMBis di Kecamatan Blanakan?

3. Sejauh mana terjadi hubungan karakteristik, jejaring komunikasi kelompok dan bagaimana motivasi pembudidaya ikan bandeng terhadap 
partisipasi dalam kegiatan KIMBis di Kecamatan Blanakan?

Tujuan yang ingin dicapai dalam penelitian ini adalah :

1. Menganalisis semua perkembangan program KIMBis di Kecamatan Blanakan;

2. Menganalisis adanya karakteristik, motivasi, jejaring komunikasi antar kelompok dan wujud partisipasi pembudidaya ikan bandeng dalam kegiatan KIMBis di Kecamatan Blanakan;

3. Menganalisis wujud suatu hubungan karakteristik, motivasi dan jejaring komunikasi dari kelompok terhadap partisipasi para pembudidaya ikan bandeng dalam kegiatan KIMBis di Kecamatan Blanakan;

Hasil penelitian ini diharapkan dapat dijadikan sebagai bahan masukan serta pertimbangan bagi stakeholder, baik penentu kebijakan di pusat, daerah, para praktisi, penyuluh perikanan, dan pembudidaya ikan bandeng itu sendiri, dalam membuat program dan kegiatan secara partisipatif yang sesuai dengan kebutuhan masyarakat setempat.

Dasar dan kerangka pemikiran penelitian ini: memfokuskan pengkajian aspek sosial terutama pada karakteristik pembudidaya ikan bandeng, jejaring komunikasi kelompok dan motivasi sebagai salah satu yang berhubungan signifikan dengan partisipasi dalam kegiatan KIMBis. Menurut Ife dan Tesorirero (2008), kegiatan partisipasi menyebabkan mobilisasi psikis dan fisik (perubahan pengetahuan, sikap, dan perilaku) petani berjalan dengan cepat karena program yang dilaksanakan sesuai dengan kebutuhan, prioritas dan kondisi sumberdaya yang akan dimiliki. Munculnya motivasi yang tinggi akan mendorong terjadinya partisipasi aktif pembudidaya ikan bandeng terhadap kegiatan KIMBis sebagai sarana untuk adopsi teknologi. Dengan adanya suatu partisipasi aktif dalam kegiatan KIMBis diharapkan akan terjadi satu perubahan pengetahuan, sikap dan keterampilan pembudidaya ikan bandeng, sehingga dapat juga meningkatkan pendapatan usahanya untuk kesejahteraan keluarga. Secara garis besar kerangka pemikiran dalam penelitian ini dapat dilihat pada Gambar 1.

Berdasarkan kerangka pemikiran diatas, hipotesis penelitian, yaitu: Karakteristik individu pembudidaya ikan (X1), Jejaring Komunikasi Kelompok (X2), Motivasi hubungan signifikan KIMBis (Y). 


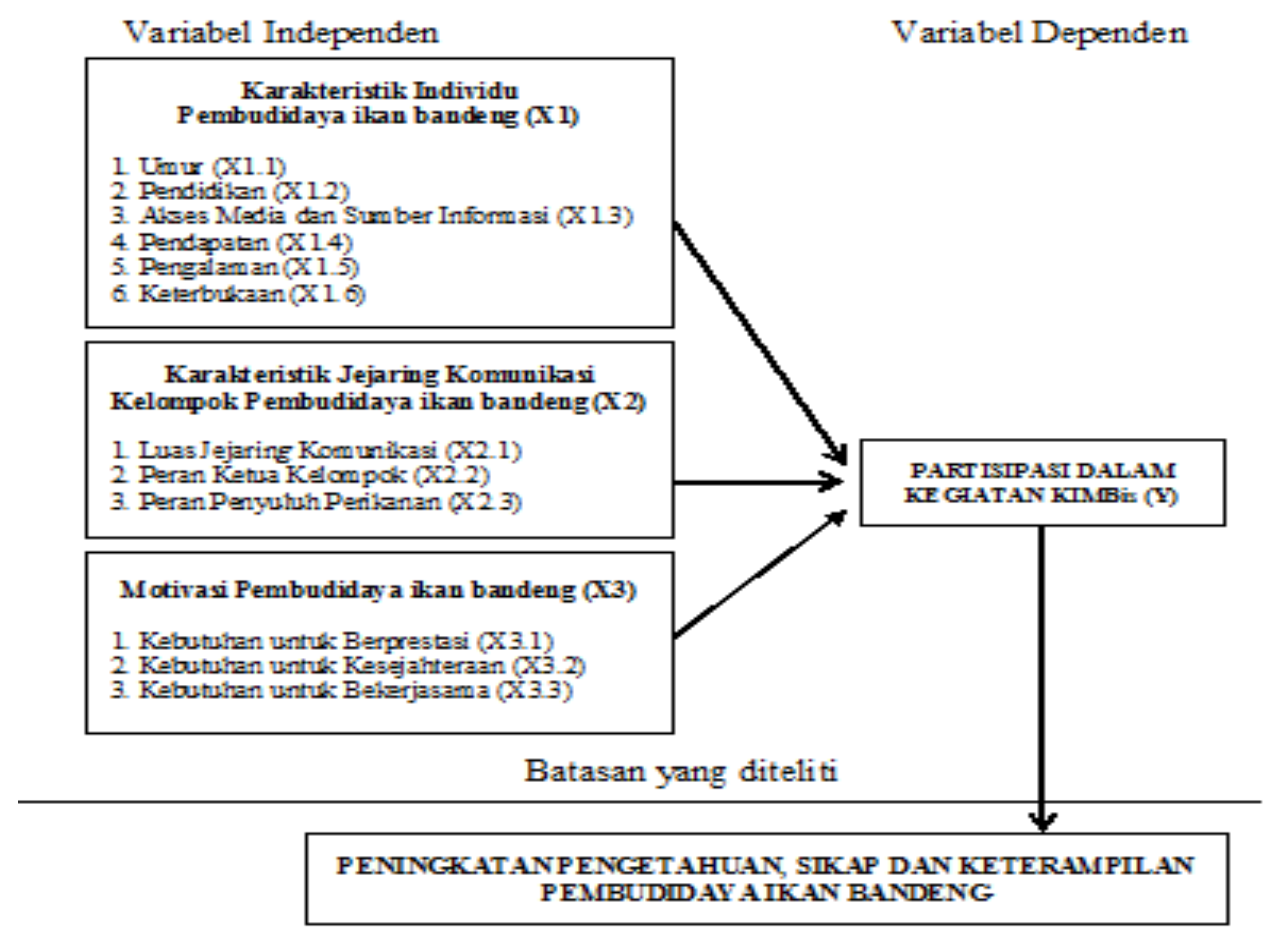

Gambar 1. Kerangka pemikiran penelitian

\section{BAHAN DAN METODE}

Metode pendekatan dalam penelitian ini menggunakan pendekatan gabungan kuantitatif dan kualitatif (mixed methods) dengan studi kasus. Penelitian ini dilaksanakan pada bulan Januari-Maret 2016 di Kecamatan Blanakan Kabupaten Subang Jawa Barat.

Populasi dalam penelitian ini 20 kelompok pembudidaya ikan bandeng yang ikut berpartisipasi dalam kegiatan KIMBis dengan anggotanya sebanyak 267 orang, sampel diambil secara proporsional di 6 lokasi. Metode yang digunakan untuk menentukan jumlah sampel menggunakan rumus Slovin dengan batas toleransi kesalahan 10\%, sehingga jumlah sampelnya sebanyak 73 orang.

Pengumpulan data dilakukan dengan cara observasi, wawancara, kuesioner dan studi dokumentasi. Data akan dianalisis dengan menggunakan korelasi Pearson Product Moment dengan nilai $\alpha=0,05$.

\section{HASIL DAN PEMBAHASAN}

Perkembangan KIMBis Subang sampai dengan saat ini telah tumbuh menjadi sebuah lembaga yang cukup 
memberi kontribusi positif terhadap upaya kemandirian masyarakat kelautan dan perikanan di Kabupaten Subang khususnya di Kecamatan Blanakan, dilihat dari luas wilayah binaan yang semula hanya di 1 Kecamatan sekarang sudah diperluas menjadi 4 Kecamatan yaitu Kecamatan Blanakan, Sukasari dan Legonkulon dan Pusakanagara dengan fokus kegiatan di budidaya air payau, penangkapan ikan, pengolahan ikan dan mangrove. Keberadaan KIMBis Subang memiliki dukungan yang cukup baik, hal ini dapat dilihat dari dukungan pemerintah daerah Kabupaten Subang terhadap keberadaan KIMBis, DKP Kabupaten Subang, SKPD terkait di Kabupaten Subang, UPT Propinsi Jawa Barat maupun Pusat, kelembagaan masyarakat yang ada di Kabupaten Subang dan respon positif dari masyarakat yang telah mengikuti kegiatan KIMBis.

Kegiatan yang sejauh ini telah dilaksanakan mencakup tujuan pertama yaitu dapat memfungsikan kelembagaan KIMBis sebagai salah satu fasilitator pengembangan bisnis dalam masyarakat dengan terwujudnya sekretariat KIMBis sebagai pada pusat informasi bisnis dan penyebaran IPTEK, serta tujuan yang kedua yaitu dapat menyusun rencana pembentukan suatu inkubator bisnis pengembangan unit usaha masyarakat kelautan dan perikanan (Erlina et al, 2014). Sementara itu, hasil penelitian yang telah dilakukan oleh Durianto et al. (2013) menyatakan bahwa program KIMBis dapat meningkatkan orientasi kewirausahaan dan kualitas sumberdaya manusia.

Lebih lanjut Erlina et al, (2014) mengatakan bahwa dalam rangka inkubasi bisnis KIMBis Subang, telah dilakukan mangrovisasi, melakukan konsultasi dengan ahli Wanamina pada Institut Pertanian Bogor (IPB), melakukan konsultasi dengan KP3K terkait dengan peluang pengadaan bibit mangrove, serta merintis peluang usaha yang dapat juga dikembangkan KIMBis sebagai suatu sumber pendanaan bagi keberlanjutan KIMBis secara mandiri. Sebagai basis unit ekonomi, KIMBis memfasilitasi suatu tahap tumbuh dan berkembangnya kegiatan perekonomian masyarakat baik di bidang perikanan tangkap, perikanan budidaya maupun pengolahan produk kelautan dan perikanan.

Selain itu, dalam kerangka menumbuhkan dan upaya kemandirian, masyarakat dibina untuk memiliki jiwa entrepreneurship yang kuat, cerdas 
Analisis Faktor-Faktor yang Berhubungan dengan Partisipasi Pembudidaya Ikan Bandeng (Chanos Chanos) dalam Kegiatan Kimbis di Kecamatan Blanakan Kabupaten Subang Provinsi Jawa Barat

Tabel 1. Hubungan Karakteristik Individu Responden Pembudidaya Ikan Bandeng dengan Partisipasi dalam Kegiatan KIMBis

\begin{tabular}{clcc}
\hline No. & \multicolumn{1}{c}{ Karakteristik Individu } & Pearson Correlation & Signifikansi \\
\hline 1 & Umur & $-0,061$ & 0,607 \\
2 & Pendidikan & 0,015 & 0,897 \\
3 & Akses Media dan Sumber Informasi & $-0,049$ & 0,683 \\
4 & Pendapatan & 0,115 & 0,331 \\
5 & Pengalaman & $-0,280$ & $0,017^{*}$ \\
6 & Keterbukaan & 0,177 & 0,135
\end{tabular}

Keterangan : * berhubungan signifikan pada $\alpha=0,05$

Tabel 2. Hubungan Karakteristik Luas Jejaring Komunikasi Kelompok Responden

Pembudidaya Ikan Bandeng dengan Partisipasi dalam Kegiatan KIMBis

\begin{tabular}{clcc}
\hline No. & \multicolumn{1}{c}{$\begin{array}{c}\text { Karakteristik Luas Jejaring } \\
\text { Komunikasi Kelompok }\end{array}$} & Pearson Correlation & Signifikansi \\
\hline 1 & Luas Jejaring Komunikasi & 0,329 & $0,004^{*}$ \\
2 & Peran Ketua Kelompok & 0,011 & 0,928 \\
3 & Peran Penyuluh Perikanan & 0,091 & 0,446 \\
\hline
\end{tabular}

Keterangan : * berhubungan signifikan pada $\alpha=0,05$

membaca setiap peluang usaha, cermat mengatur data keuangan, bijak dalam menyelesaikan permasalahan, mampu menjalin kerjasama anggota, serta selalu mempunyai semangat untuk terus maju dan selalu memiliki daya saing tinggi (Erlina et al, 2014). Hasil penelitian menunjukkan bahwa suatu karakteristik individu dapat berupa pengalaman berpengaruh signifikan negatif terhadap partisipasi dalam kegiatan KIMBis artinya bahwa dengan semakin lama pengalaman para pembudidaya dalam melakukan kegiatan usahanya, maka partisipasinya dalam kegiatan KIMBis akan semakin rendah, berbeda dengan yang sedikit pengalaman usahanya maka para pembudidaya itu tingkat partisipasinya akan semakin tinggi. Berdasarkan suatu hasil pengamatan dilapangan seorang pembudidaya yang sudah berpengalaman lama cukup sulit untuk berkelompok dan tentunya juga sulit terlibat dalam kegiatan KIMBis, karena sasaran dari KIMBis merupakan kelompok masyarakat kelautan dan perikanan, lebih lanjut dipertegas oleh penelitian yang pernah dilakukan oleh Herawati \& Pulungan (2006) serta Salampessy et al. (2010).

Karakteristik perluasan jejaring komunikasi kelompok pembudidaya ikan bandeng yang berhubungan 
signifikan searah dengan partisipasi dalam kegiatan KIMBis adalah luas jejaring komunikasi, artinya semakin luas jejaring komunikasi pembudidaya ikan bandeng maka semakin tinggi partisipasinya dalam kegiatan KIMBis, hal ini sejalan dengan penelitian yang telah dilakukan oleh Herawati dan Pulungan (2006), Atawollo (2012) dan Suroso et al. (2014).

Peran para ketua kelompok pembudidaya yang tidak berhubungan signifikan dengan partisipasi dalam kegiatan KIMBis, karena berdasarkan hasil kerja pengamatan dilapangan menunjukkan bahwa ketua kelompok jarang melakukan pertemuan yang rutin kelompok dengan anggotanya, sehingga peran ketua kelompok yang seharusnya menjadi pemimpin yang dalam setiap pertemuan rutin dengan kelompoknya, menyampaikan tentang informasi baru yang diperoleh dari kegiatan KIMBis, hal ini tidak dilakukan sehingga peran para ketua kelompok tidak berhubungan signifikan dengan tingkat partisipasi dalam satu kegiatan KIMBisi, berbeda dengan penelitian yang sudah dilakukan oleh Yunasaf (2005) menyatakan bahwa hubungan kepemimpinan para ketua kelompok dengan keefektifan kelompok adalah positif dan kuat. Sementara itu penelitian dari Restuwati (2012) juga menyatakan bahwa peran ketua kelompok dengan gambaran indikator perkembangan kawasan Minapolitan berhubungan signifikan.

Peran penyuluh perikanan tidak berhubungan signifikan dengan partisipasi kegiatan KIMBis, berdasarkan pengamatan dilapangan, kunjungan penyuluh perikanan kepada kelompok jarang dilakukan, hal ini karena jumlah penyuluh perikanan satu orang dengan luas wilayah binaan empat Kecamatan. Penelitian yang pernah dilakukan oleh Abdullah (2008) menyatakan bahwa keberhasilan tahap penyuluhan ditentukan oleh model penyuluhan yang sesuai dengan kebutuhan, yaitu ketepatan materi, metode dan media yang digunakan. Sementara itu Ramadoan et al. (2013) menyatakan bahwa peran para penyuluh swadaya masyarakat berhubungan signifikan dengan peningkatan fungsi kelompok. Dalam hal ini, berdasarkan atas hasil penelitian Berlian (2014) bahwa peran penyuluh pertanian cukup signifikan dengan partisipasi petani dalam suatu program FEATI. 
Tabel 3. Hubungan karakteristik motivasi responden pembudidaya ikan bandeng dengan partisipasi dalam kegiatan KIMBis

\begin{tabular}{clcc}
\hline No. & \multicolumn{1}{c}{ Karakteristik Motivasi } & Pearson Correlation & Signifikansi \\
\hline 1 & Kebutuhan untuk Berprestasi & 0,128 & 0,280 \\
2 & Kebutuhan untuk Kesejahteraan & 0,301 & $0,010^{*}$ \\
3 & Kebutuhan untuk Bekerjasama & 0,137 & 0,247 \\
\hline
\end{tabular}

Keterangan : * berhubungan signifikan pada $\alpha=0,05$

Berdasarkan suatu hasil analisis diketahui bahwa kebutuhan untuk kesejahteraan responden pembudidaya berhubungan signifikan positif dengan partisipasi dalam kegiatan KIMBis, artinya semakin tinggi keinginan pembudidaya untuk merubah hidupnya menjadi lebih sejahtera, maka tingkat partisipasinya semakin tinggi, berbeda dengan pembudidaya yang sudah mapan atau sejahtera maka partisipasinya akan rendah. berdasarkan hasil pengamatan dilapangan untuk pendapatan responden pembudidaya ikan bandeng mayoritas antara Rp 1.800.000 - Rp 2.550.000 masih tergolong cukup rendah, hal ini yang menyebabkan kebutuhan untuk kesejahteraan berhubungan signifikan dengan tingkat partisipasi pada kegiatan KIMBis, sejalan dengan hasil penelitian Dewi (2006), Suprayitno et al. (2012). Sementara itu Berlian (2014) dalam penelitiannya menyatakan bahwa partisipasi petani dalam program FEATI dapat mempengaruhi pendapatannya.
Kebutuhan untuk bekerjasama responden para pembudidaya tidak saja berhubungan cukup signifikan dengan partisipasi dalam kegiatan KIMBis, dari pengamatan dilapangan dan data-data yang diperoleh menunjukkan bahwa responden para pembudidaya sudah melakukan kerjasama yang baik antara individu pembudidaya maupun dalam kelompok yang sudah ada terbentuk sebelum ikut dan berpartisipasi dalam kegiatan KIMBis, sementara itu hasil penelitian Nofrida (2014) menunjukkan bahwa iklim kerjasama berhubungan signifikan dengan semangat kerja pegawai, dalam hal ini Simanungkalit (2012) menyatakan bahwa kerjasama berhubungan positif terhadap efesiensi kerja.

\section{SIMPULAN}

1. Perkembangan Klinik IPTEK Mina Bisnis Subang sampai dengan saat ini dilihat dari luas wilayah binaan yang semula hanya fokus pada satu 
Kecamatan saat sekarang diperluas menjadi empat Kecamatan yaitu Kecamatan Blanakan, Sukasari, Legonkulon dan juga Pusakanagara dengan fokus kegiatan budidaya air payau, kegiatan penangkapan ikan, pengolahan ikan serta mangrove. Keberadaan KIMBis Kabupaten Subang memiliki dukungan yang cukup baik dari pemerintah daerah Kabupaten Subang, serta DKP Kabupaten Subang, SKPD terkait di Kabupaten Subang, UPT Propinsi Jawa Barat maupun Pusat, kelembagaan masyarakat yang ada di Kabupaten Subang dan respon positif masyarakat yang telah mengikuti unit kegiatan KIMBis. Budidaya sistem polyculture antara udang windu, bandeng dan rumput laut ternyata mampu memberikan penghasilan tambahan yang cukup bagi pembudidaya dibandingkan dengan hanya pada sistem budidaya monoculture. Dalam menunjang pelestarian sumber daya mangrove dan tetap mendukung terhadap pengembangan budidaya dari ikan bandeng dengan sistem budidaya policulture, dilakukan diversifikasi unit usaha dengan mengembangkan kawasan area budidaya ini menjadi kawasan ekowisata wanamina.

2. Karakteristik individu responden pembudidaya ikan bandeng terdiri dari a) umur yang dominan antara 34-45 tahun; b) pendidikan yang dominan lulusan SLTA; c) suka atau sering mengakses media dan sumber informasi terutama melalui media elektronik berupa televisi dengan nilai skor sebesar 288; d) pendapatan yang paling dominan antara besaran Rp. 1,800,000 Rp. 2.550.000; e) pengalaman paling dominan antara 5-12 tahun; f) keterbukaan paling dominan dengan frekuensi dua kali sebulan. Karakteristik paling luas jejaring komunikasi kelompok responden pembudidaya terdiri dari luasan jejaring komunikasi, peran ketua kelompok dan peran penyuluh perikanan dengan nilai skor ratarata sebesar 256. Karakteristik motivasi responden pembudidaya ikan bandeng terdiri dari kebutuhan untuk berprestasi, kebutuhan untuk kesejahteraan dan kebutuhan untuk bekerjasama dengan nilai skor ratarata sebesar 305. Karakteristik partisipasi responden pembudidaya ikan bandeng terdiri dari partisipasi 
Analisis Faktor-Faktor yang Berhubungan dengan Partisipasi Pembudidaya Ikan Bandeng (Chanos Chanos) dalam Kegiatan Kimbis di Kecamatan Blanakan Kabupaten Subang Provinsi Jawa Barat

dalam perencanaan, pelaksanaan dan pemanfaatan hasil dengan nilai skor rata-rata sebesar 282 .

3. Dari hasil analisis menggunakan korelasi Pearson Product Moment dengan nilai $\alpha=0,05$ menunjukkan bahwa yang telah berhubungan signifikan dengan tahap partisipasi responden para pembudidaya ikan bandeng dalam kegiatan KIMBis adalah pengalaman, luas jejaring komunikasi dan kebutuhan untuk kesejahteraan.

\section{SARAN}

Berdasarkan hasil pembahasan dan kesimpulan yang telah dijelaskan sebelumnya, saran-saran yang dapat disampaikan dalam rangka terbentuknya kelembagaan KIMBis sebagai fasilitator bisnis masyarakat dan inkubator bisnis berbasis IPTEK di Kabupaten Subang untuk meningkatkan perekonomian masyarakat lokal yaitu:

1. Saran yang terkait dengan tujuan penelitian pertama

a. Pemerintah tingkat daerah Kabupaten Subang perlu memfasilitasi sarana dan prasarana serta memberikan bantuan dana operasional kegiatan KIMBis. b. DKP Kabupaten Subang perlu adanya peningkatan kegiatan teknis perikanan maupun administrasi dalam mendukung suatu kegiatan operasional KIMBis serta menambah alokasi bantuan sarana bagi semua kelompok binaan KIMBis.

c. BP4K2P dengan BBPSEK KP perlu berkoordinasi terkait dengan adanya unsur penyuluh perikanan yang masuk dalam kepengurusan unit KIMBis Subang.

d. KIMBis Pusat dalam hal penerapan tingkat Teknologi Adaftif Lokasi atau TAL. KIMBis harus mempunyai lokasi dempond sendiri.

e. Sebagai satu upaya kearah kemandirian unit KIMBis Subang terutama dalam hal pendanaan dalam kegiatan KIMBis, perlu ada yang merintis usaha produktif seperti kegiatan pengelolaan ekowisata wanamina.

f. DKP Kabupaten Subang dengan BBPSEK KP perlu memfasilitasi suatu kelompok sasaran KIMBis untuk studi 
banding ke daerah yang terlihat berhasil didalam melaksanakan satu kegiatan usahanya.

1. Saran yang terkait dengan tujuan penelitian kedua:

PUSLUHDAYA KP diperlukan menambah jumlah penyuluh perikanan di lokasi kegiatan KIMBis.

2. Saran yang terkait dengan tujuan penelitian ketiga :

Ketika mencari kelompok baru untuk dibina KIMBis harus memperhatikan pengalaman pembudidaya, luas jejaring komunikasi dan kebutuhan untuk kesejahteraan agar partisipasinya tinggi dalam kegiatan KIMBis.

\section{DAFTAR PUSTAKA}

Abdullah A. 2008. Peranan penyuluhan dan kelompok tani ternak untuk meningkatkan adopsi teknologi dalam peternakan sapi potong. Prosiding Seminar Nasional. November 2008. Hal. 188-195

Atawollo A. 2012. Pengaruh efektivitas komunikasi kelompok dan tingkat partisipasi anggota terhadap kemandirian kelompok dalam program bantuan pemberdayaan ekonomi masyarakat di Kecamatan Amarasi Selatan Kabupaten Kupang [disertasi].
Yogyakarta. Universtitas Gadjah Mada.

Berlian M. 2014. Peran penyuluh pertanian lapangan dan partisipasi petani dalam program FEATI serta pengaruhnya terhadap pendapatan petani di Kecamatan Banyuasin III Kabupaten Banyuasin. Jurnal Matematika, Saint dan Teknologi. Maret 2014. Vol. 15 (1): 52-62

Dewi K. 2006. Analisis beberapa faktor yang mempengaruhi partisipasi karyawan (suatu kajian teori). Buletin Studi Ekonomi. Vol. 11 (1): 10-18

Erlina DM, N Kurniasari, RH Dewi, FN Friyatna, dan T Bualangi. 2014. Laporan akhir program rintisan pengembangan kelembagaan dan perekonomian kawasan berbasis IPTEK (KIMBis Subang). Jakarta. Balai Besar Penelitian Sosial Ekonomi Kelautan dan Perikanan (BBPSEKP). Hal. 1-42

Herawati dan I Pulungan. 2006. Faktorfaktor yang berhubungan dengan partisipasi kontak tani dalam perencanaan program penyuluhan pertanian (Kasus areal WKUPP Nyalindung, kawasan Kabupaten Sukabumi). Jurnal Penyuluhan. Vol. 2 (2): 108-114

Ife J, dan F Tesorirero. 2008. Community development, suatu alternatif pengembangan masyarakat di era globalisasi. Diterjemahkan dari Community-based alternatives in an angel of globalisation oleh S Manullang, N Yakin, M Nursahid. Yogyakarta. Pustaka Pelajar. 721 Halaman 
Junaidi D. 2015. KIMBis meningkatkan produktivitas UMKM http:// technology indonesia.com component/ content/article/ $744-$ dedi-junaedi. [2 Des 2015].

Nofrida E. 2014. hubungan iklim kerjasama dengan semangat kerja pegawai pada dinas pendidikan Kota Solok. Jurnal Administrasi Pendidikan, Vol. 2 (1): 187-831

Restuwati I. 2012. Hubungan karakteristik pembudidaya ikan lele dan jejaring komunikasi kelompok dengan perkembangan minapolitan di Kecamatan Ciseeng Bogor. Jakarta. Universitas Terbuka

Ramadoan S, P Muljono, dan Pulungan I. 2013. Peran PKSM dalam meningkatkan fungsi kelompok tani dan partisipasi masyarakat di Kabupaten Bima Nusa Tenggara Barat. Hal. 199-210

Simanungkalit RD. 2012. Analisis hubungan kerjasama tim untuk meningkatkan efesiensi kerja pada PT Mitha Samudera Wijaya Medan. Hal. 1-14

Suprayitno RA, Sumardjo, DS. Gani, dan BG Sugihen. 2012. Motivasi dan partisipasi petani dalam pengelolaan hutan kemiri di Kabupaten Maros Provinsi Sulawesi Selatan. Jurnal Penyuluhan Vol. 8 (2): 184-199

Suroso H, A Hakim, dan I Noor. 2014.

Faktor-Faktor yang Mempengaruhi Partisipasi Masyarakat dalam Perencanaan Pembangunan Di Desa Banjaran Kecamatan Driyorejo Kabupaten Gresik. Jurnal Wacana. Vol. 17. No. 1. Hal. 7-15
Yunasaf U. 2005. Kepemimpinan ketua kelompok dan hubungannya dengan keefektifan kelompok. Hal. 1-16 